\title{
Co-Creating Desired Outcomes and Strengthening the Resilience of Multi-Challenged Families
}

Nina MeŠL ${ }^{\star 1}$ ANd TAdeJA KodelE ${ }^{2}$

$\approx$ Families facing poverty suffer from many other stresses, with children's school performance being one of the common topics. A life of poverty and the related unfavourable circumstances should not define children's life stories. Ensuring this is not the case is partly the responsibility of professionals working with families. It is important to overcome the problem of the frequently dispersed help given to multi-challenged families. We proceed from the premise that the vicious circle of failures can be broken by providing support and help to the family and by establishing a co-creative working relationship involving all of the participants in a joint working project. The results of the plural case study confirmed the importance of working with multi-challenged families, which includes dealing with the children's poor school performance, in their homes. They also showed the inadequacy of the often dominant discourse claiming that families do not want to receive help. The results prioritise the role of social workers and the relationship established at the beginning of the collaboration with the family. The presence of a social worker who persists with a joint project even in the case of failure represents an important new experience for families. Although multi-challenged families are resilient, they sometimes need an interlocutor to help them recognise and strengthen that resilience.

Keywords: co-creative working relationship, individual working project of help, poor school performance, poverty, working with the family at home

$1 \quad{ }^{*}$ Corresponding Author. Faculty of Social Work, University of Ljubljana, Slovenia; nina.mesl@fsd.uni-lj.si.

2 Faculty of Social Work, University of Ljubljana, Slovenia. 


\section{Soustvarjanje želenih izidov in krepitev odpornosti družin s številnimi izzivi}

Nina Mešl in Tadeja Kodele

$\propto$ Družine, ki se srečujejo z revščino, se spoprijemajo še s številnimi drugimi izzivi. Pogosta tema je tudi šolska neuspešnost otrok. Začetek življenja $\mathrm{v}$ revščini in s tem povezane neugodne okoliščine ne smejo definirati otrokove življenjske zgodbe, za kar smo soodgovorni strokovni delavci, ki sodelujemo z družinami. Pomembno je preseči problem pogoste razpršenosti pomoči, ki so je deležne družine s številnimi izzivi. Izhajava iz teze, da se začaran krog neuspehov lahko prekine s procesom podpore in pomoči družini, soustvarjenim v delovnem odnosu, ki v skupni delovni projekt poveže vse udeležene. Rezultati pluralne študije primera so potrdili pomen sodelovanja z družinami, ki se ob številnih izzivih spoprijemajo še s problemom šolske neuspešnosti otrok, na njihovih domovih. Pokazali so tudi na neustreznost pogosto prevladujočega diskurza, da družine niso naklonjene prejemanju pomoči. Rezultati v ospredje postavljajo vprašanje vloge strokovnega delavca in odnosa, ki ga vzpostavi, ko vstopa v sodelovanje $\mathrm{z}$ družino. Pomembna nova izkušnja za družine je zavzeta prisotnost socialne delavke, ki vztraja tudi ob morebitnih neuspehih v skupnem projektu. Družine s številnimi izzivi so odporne, a včasih potrebujejo sogovornika, ki jim pomaga odpornost prepoznati in jo krepiti.

Ključne besede: revščina, šolska neuspešnost, delovni odnos soustvarjanja, izvirni delovni projekt pomoči, sodelovanje z družino na domu 


\section{Introduction}

Modern society gives individuals more choices, including those related to the organisation of family life. New opportunities bring new demands, tensions and challenges. Family life has always implied a constant search for a way to meet individual and family needs, making more room for various roles, connections and negotiations, as well as the challenges of handling conflicts. Each family structure is very complex, and the various life circumstances the family faces further increase this complexity.

In Slovenia, many families suffer from poverty due to various social circumstances. It is well known that few life contexts bring more adversities and uncertainties than poverty (Maholmes, 2014, p. 4), and that poverty affects people's health, family relationships, the role of the family in the community, etc. Research (ibid.) also indicates a high correlation between poverty and poor educational achievements, bad health and behavioural problems. Life in severe and long-term poverty represents a risk factor for children at a later age as well, increasing the possibility of economic difficulties and related problems in adulthood.

The project "Helping Families in the Community: The Co-Creation of Desired Changes for Reducing Social Exclusion and Strengthening Health"3 aimed to co-create possible ways of overcoming the dominant family stories of exclusion, helplessness and despair, often passed down from generation to generation and created by a life in poverty and the related experience of many stresses. The collaborative projects of help aimed to find a path to the desired changes, to increased hope and power, and to the co-creation of new, empowering experiences and stories.

We worked with several families with different backgrounds, all of whom shared the experience of poverty. The present article presents the results of selected individual working projects of help (hereinafter: IWPH) for families who were, among other problems, faced with the children's poor school performance.

We proceed from the premise that the vicious circle of failures can be broken by a process of providing help to the family in a co-creative working relationship (Čačinovič Vogrinčič, Kobal, Mešl, \& Možina, 2005) between all of the participants, involving people from various areas associated with family problems in a joint working project. We can thus overcome the problem

3 The article was written within a project funded by the Norwegian Financial Mechanism and the Government Office for Development and European Cohesion Policy from 16 February 2015 to 30 September 2016. 
of the frequently dispersed help given to multi-challenged families, ${ }^{4}$ in which each professional begins working with the family by focusing on one part of the problem. Bouwkamp and Bouwkamp (2014, p. 301) provide a vivid description of the issue of dispersion in the processes of help to multi-challenged families using the metaphor of a broken car that is being repaired in different garages, hoping that the problem will be solved once the car is re-assembled. To make it worse, many professionals who eagerly deal with the problems of families in detail in different separated areas represent the burden of multiple entries to and exits from family life. It is, however, unacceptable that the family is left without the required help in the end, despite the intervention of numerous professionals.

In the process of working with families within the project, the topic of children's poor school performance was often considered. Although numerous studies (e.g., in Boyd-Franklin \& Hafer Bry, 200o; Maholmes, 2014) indicate the vicious circle of the early experience of poverty, poor school performance, premature school leaving, unemployment in adulthood, etc., there are some rarely highlighted stories that testify to the fact that children living in poverty can succeed and live well despite all of the risks. Although the circumstances related to their economic situation do not change significantly, some children and their families manage to cope with or overcome many consequences of poverty ${ }^{5}$ (Maholmes, 2014, p. 4). The topic of (poor) school performance often represented the starting point for collaboration with the family, opening the door to the research of other complex topics in a non-threatening way. The experience of working on the project once again confirmed that many parents

4 We have borrowed the terminology used by Melo and Alarcão (2011). These are families that are usually considered vulnerable families (Sharlin \& Shamai, 2000), multi-stressed families (Madsen, 2007) and multi-problems families (Walsh, 2006). In daily life, they face numerous internal and external stressors that are often associated with difficult living conditions, leading to overload and destabilisation in the family. Many of these families fail to meet the basic needs, and they constantly face various challenges (e.g., job search with little possibility of employment, low incomes for survival, the inability to help children with school matters, or the burdens of disease, addiction, abuse, violence, oppression and homelessness). Most importantly, all of these families experience poverty (Melo \& Alarcão, 2011). We decided to use this term mainly because we wanted to emphasise that the families involved in the project are much more than the problems they face. In cooperation with them, we were not focused on "what is missing and what should be", but on "what is and what could be" (Madsen, 2007). Terms organise our way of experiencing and interacting with people. We hope that the terminology will contribute to the recognition of the richness and colourfulness present in the life of these families, even if they suffer from many kinds of stress and multiple pressures of everyday life.

5 We certainly do not want to diminish the importance of the social changes that are necessary to overcome the terrible conditions in which children and families live. We believe that it is unacceptable that the state does not provide the conditions to ensure people, especially children, a decent life. The article examines processes that increase the resilience of children and families, which are understood as processes that need to be carried out together with the critical systemic changes that we should all promote. 
want the best for their children; they want their children to experience success and they make great efforts to support them, but they often cannot do this by themselves due to all of the stress and pressure. The experience of good school performance is indeed significant, not only for knowledge development, but also as an inspiration for developing and realising dreams, for discovering talents, and for creating the space for children to nurture the vision that they can be someone who matters in this world. This is particularly important for families facing poverty, as their circumstances can overwhelm their dreams and visions of a brighter future (op. cit., p. 73).

The present article first briefly presents the idea of the project and its basic concept, which served as a foundation for the collaboration with families in the community. ${ }^{6}$ It then presents the results of action research, discussing key theoretical emphases. The latter are understood as a possible support for multi-challenged families, but also as an opportunity for a child to achieve good school performance, an outcome that adults are obliged to enable.

\section{Presentation of the Project with the Key Theoretical Basis}

In the 2013/2014 academic year, the Faculty of Social Work carried out the "Co-Creation of Help for Families in the Community" pilot project within the "Social Work with Families" master's programme. The experience gained in the pilot project encouraged us to continue and upgrade our work. In February 2015, we thus initiated the project "Helping Families in the Community: The Co-Creation of Desired Changes for Reducing Social Exclusion and Strengthening Health", which was implemented within the framework of the 2009-2014 Norwegian Financial Mechanism and involved the University of Ljubljana (Faculty of Social Work, Faculty of Sport and Faculty of Health Sciences) and two partners: Norges Teknisk-Naturvitenskapelige Universitet from Norway and the Ljubljana Moste-Polje Association of Friends of Youth. The objectives of the project were to co-create changes with family members in order to reduce health inequalities, to create a model of help for families in the community, and to train professionals for working in the areas of the participating faculties. ${ }^{7}$ Below, we will focus on the work of the Faculty of Social Work. In both the pilot and the current project, the students, who had already completed

6 Within the project, helping families in the community is understood as providing help in their homes, i.e., in the communities in which they live. The IWPH co-created with the family is linked to other resources in the community that can support the family in making the desired changes (e.g., school, social work centre, charitable organisations, relatives, neighbours).

7 More about the project can be found at: http://spdse.splet.arnes.si/. 
undergraduate studies at the Faculty of Social Work, entered into the processes of providing help to multi-challenged families independently. When carrying out practical work, they had intense and continuous support from small mentoring groups, as well as the possibility of regular individual consultations with their mentor at the faculty. The students visited the families independently in their homes and co-created the desired outcomes in a working relationship with family members (Čačinovič Vogrinčič, Kobal, Mešl, \& Možina, 2005).

The concept of a working relationship in social work defines the users and social workers as associates in a joint project with the mission of co-creating the solution. The working relationship helps the social worker to start a conversation with the family, allowing him or her to examine and co-create the desired outcomes (Čačinovič Vogrinčič, 2008). The social worker is an appreciative and accountable ally of the family (Madsen, 2007).

During the academic year, each student collaborated with at least one family and set up an IWPH (Čačinovič Vogrinčič, 2006). The working relationship enables solutions to people's complex problems to be provided as an individual working project. The projects are individual because they are developed separately for each family; they are co-created with the family and for the family. The projects are called working because they are focused on work, collaboration and the activities that follow the work carried out in the working relationship. We talk about projects because they pass in time and are directed towards positive outcomes (Čačinovič Vogrinčič, 2008).

When ensuring collaboration and further work with the families, we proceeded from the premise that multi-challenged families are resilient (Walsh, 2006). Although the families suffer considerable distress, the students noticed many sources of strength.

"Despite all of the distress, the mother had hope; she remained patient with the children, she fought for survival and for her children like a lion, and she took care of the household, hoping that she could go back to work and that the girls would become more independent." $\left(F_{15}\right)^{8}$

The basic principle of the work was also the understanding of Madsen (2007) and his belief that multi-challenged families are much more than the problems they face. When collaborating with them, we did not focus on "what is not there and what should be", but on "what is there and what could be".

8 For the explanation of the excerpts' indication see Data Collection (p. 58). 


\section{Method}

\section{Definition of the Research Problem}

In the current and pilot projects, we collaborated with multi-challenged families. The challenge was how to support these families in the transition from the old problems to the new future. Family members were mostly facing poverty and social exclusion, while (poor) school performance often represented an important working topic. Although the parents wanted and were willing to help their children, they were often helpless; they did not know how to help them or were unable to do so, especially because they were burdened with other problems.

The research was based on the following research questions:

- How can we use social work concepts when helping families in community that face many challenges, including poor school performance?

- How can helping families with a child's poor school performance support the family in other areas?

- What was the role of the student in helping multi-challenged families with poor school performance?

- How did the participants in the IWPH experience collaboration in the family home?

\section{Type of Research}

The research is qualitative. The data was collected using a plural or extended case study and was analysed using the method of qualitative analysis (Mesec, 1998).

\section{Population and Sampling}

The sample of the research were the families involved in the pilot and current projects. The pilot project included 11 families and the current project 28 families. The results presented in the article involve seven families (four from the current project and three from the pilot). The selection of the families was based on their involvement in IWPHs in which a child's poor school performance represented an important working topic.

\section{Data Collection}

Within the action project, a great deal of material was collected for evaluating the draft model of working with families in the community and for 
the development of new knowledge. At the beginning of the collaboration, the students conducted an interview with the family, exploring the initial expectations of family members. In the middle of the collaboration, they carried out an interim evaluation with the family, which was followed by the final evaluation at the end of the collaboration. The purpose of the evaluations was to obtain feedback on the collaboration between the student and the family. At the end of the collaboration, the students wrote a final paper presenting the process of working with the individual families based on an analysis of the meeting records made after every visit. Recording forms with predefined categories (e.g., agreement on collaboration, strength perspective, ethics of participation) were created to facilitate the regular and professional recording of the work process. At the end of the collaboration, the researchers conducted in-depth interviews with the families.

The present article discusses findings obtained by exploring the initial expectations of the family members, as well as through final evaluations, one interim evaluation and the final papers analysing the processes of working with the families. All of the material refers to IWPHs in which a child's poor school performance represented an important working topic.

Excerpts from the students' final papers written within the pilot project were marked with the letter $P$ (pilot project) and with the serial number of the family (e.g., final paper from the pilot project - family no. 9: PF9). Excerpts from the students' final papers written within the current project were marked in a similar way, but without the letter $\mathrm{P}$ (e.g., final paper from the current project - family no. 9: F9). Statements relating to the initial expectations of individual family members in the current project were marked with the letter $\mathrm{E}$ (for expectations), as well as with the number of the question, the number of the family and the first letter of the individual family member (e.g., the mother's answer to the first question about expectations - E1.F9M.1). The last number indicates the serial number of the statement. The statements from the pilot project included the letter $\mathrm{P}$ at the beginning (e.g. PE1.F9M.1). Similarly, we marked the statements of the individual family members from the interim and final evaluations using the letter I instead of the letter E for the interim evaluation (e.g., I1.F9M.1) and the letters FE for the final evaluations (e.g., FE1.F9M.1).

\section{Data Analysis}

The collected data was analysed using the method of qualitative analysis (Mesec, 1998). The analysis included material from the initial expectations, the interim and final evaluations, and the final papers of both projects. From the 
material collected, statements that were relevant to the defined research problem were selected for analysis. To begin with, qualitative analysis of a final paper was undertaken by breaking it into meaningful code units (individual sentences or paragraphs) and attributing an adequate term to these units based on the content (direct designation - Mesec, 1998, p. 107). The terms were selected on the basis of theory and common sense. Other final papers were then analysed in the same way, searching for similarities and differences with regard to the first analysed final paper. The statements were grouped according to common codes and the obtained terms were grouped into higher-level categories. Increasingly transparent material was thus obtained and a vocabulary of terms of the emerging experimental theory was drafted by defining this material. The initial expectations and interim and final evaluations were then analysed in the same way.

\section{Results}

Learning Assistance as the Beginning of Collaboration with the Family in the IWPH

The students collaborated with multi-challenged families dealing with complex problems that affect everyday life in the family and the community. Most of the families suffered immense financial and housing distress for various reasons (e.g., single-parent families, unemployment, problems with benefiting from public funds, debt, one parent leaving the family). The problems of poverty bring many additional pressures (see e.g., Walsh, 2006; Maholmes, 2014). In the participating families, problems piled up (domestic violence, drug addiction, suicide attempts, health problems, problems associated with raising children). Difficult life circumstances often caused troubled relationships within the family, burdening both parents and children. All of the selected families also suffered from children's learning difficulties. School performance is often a central topic in multi-challenged families, as is evident from the present project. This was observed when exploring the initial expectations of families at the beginning of the collaboration. The families mainly decided to participate in the project because the parents wanted the best for their children.

"She was worried because F9S1 got nothing but fail grades, and she was afraid he would have to repeat the third year. She said that she sometimes did not know how to help him and that they sometimes did homework for hours." (SF9) 
The parents expected the students to help their children do their homework and offer learning assistance.

"And I would like you to give learning assistance to my children. Especially to $\mathrm{F}_{9} \mathrm{~S}_{1}$, but also to $\mathrm{F}_{9} \mathrm{D}$ in chemistry and maths." (E1.F9M.2)

At the beginning of the collaboration with the families, the purpose of the joint work was mostly defined as supporting and helping children with schoolwork, as well as socialising with them.

"We agreed that I would help $F_{15} D_{1}$ and $F_{15} D_{2}$ with their homework and other schoolwork." (F15)

The students wanted to help the children and relieve their parents. The parents also verbalised their relief.

"Now, when you visit me once a week, I can talk about what is bothering me. I feel relieved." (E1.F9M.1)

Learning assistance, socialisation and relief of the parents represented entry points for collaboration with the family. Both children and parents needed some time to establish trust with the students.

"During our third meeting, F15M opened up and shared her distress, helplessness and despondency with me." (F15)

\section{Learning Assistance in the Co-Creative Working Relationship}

When working with families in the IWPH, the students realised how important it is to reach agreement with the family on collaboration and to establish a working relationship (Čačinovič Vogrinčič, Kobal, Mešl, \& Možina, 2005).

"We agree on how we will work together. We agree on the future collaboration with the family and the girl based on regular weekly visits, with an emphasis on learning assistance to $F_{21} D_{1}$ in various subjects, especially English and maths. It is necessary to help F21D1 improve all of the fail grades. Before every hour of learning assistance, we talked about current affairs and about the situation in the family. We meet every second Friday for two hours." (F21)

The personal involvement of the student was also important. Being personally involved, reacting personally and sharing one's experience or story represents a starting point for personal leading (Bouwkamp \& Vries, 1995) as a basic element of working relationships. The experience of respect and dignity, 
which is essential for social work with multi-challenged families, can only become a personal experience in dialogue and collaboration (Čačinovič Vogrinčič et al., 2005, p. 11).

"Due to the focus on the personal relationship, I noticed the first shift, a turning point when $F_{21} D_{1}$ showed me her drawings and colouring books. This is when I shared my personal story with her and presented a view on possible solutions" (F21)

Co-creating solutions together with the family and the child was particularly important.

"In family F21, the initial instrumental definition of the problem was given over and over again, at every meeting. I explored her contribution to the solution together with the user. F21D1 repeatedly gave her own definition of the problem, while I contributed my vision. This was the only way to work towards the possible, the achievable. I always respected her experience and we worked on an achievable solution for every problem encountered in understanding the subject matter." (F21)

While offering children learning assistance and working with the entire family on other working topics, the students mainly relied on the concept of strength perspective (Saleebey 1997) and the ethics of participation (Hoffman, 1994). They gave children an opportunity to express their opinions and suggestions.

"I realised how important it is to examine the problem and to trace exceptions, as well as to co-create solutions. When I discussed with PF11D what she was afraid of and what the test should look like, she became less afraid and we were finally able to move forward. If we had worked solely on learning the subject matter, PF11D would still be afraid of tests." (PF11)

The students proceeded from the premise that children are experts on experience, thus giving up power they were not entitled to, i.e., that they are the sole owners of all knowledge and truths. Consequently, they provided the child with a valuable experience of co-creation in the process of learning and help (Čačinovič Vogrinčič, 2013).

"When I asked F21D1 where she sees her skills and knowledge, she replied that she is good, for example, at maths, because she understands the subject matter. She knows that she can learn it and that she is competent. She just needs some additional explanation, something more understandable than that given in school." (F21) 
The students repeatedly joined the families in their realities, meanings and stories. The children thus gained the feeling that the students understood them, which was essential for successful collaboration.

"When I showed understanding of the fact that he does not feel like doing his homework, our relationship got a new energy. I believe that $\mathrm{F}_{9} \mathrm{~S}_{1}$ felt that I understand him, that I am O.K. with the fact that he does not feel like doing homework and that I find it completely normal. When he saw that this does not just happen to him, but also to me and to other people, he did not feel like an isolated case of laziness (as F9M often said), but as a completely normal pupil who does not enjoy doing homework." (F9)

When working with the family and providing children with learning assistance, the students found it useful to praise the children and the parents and to pay them compliments, which is also the basis for solution-focused brief family therapy (Jong \& Kim Berg, 2002). Compliments are one of the elements that help create solutions. They are used in social work with families throughout the entire process of work. We can certainly conclude a conversation with compliments that have developed during the working relationship.

"When he said something like this, I tried to show him how well he had done the last assignment or where he had been successful. After we finished his homework, I always praised him for sitting through to the end, even though he does not like doing homework and would prefer doing something else. When he was praised at school, I also paid him a compliment." (F9)

The students found that working from the strength perspective (Saleebey, 1997) contributed to the child's increased motivation for participation and schoolwork. It also contributed to the formulation of long-term objectives and the child's desired outcomes in the project of help.

"As a result, the motivation increased and he started studying independently. He managed to improve most of the fail grades by the time of my last visit. His progress was obvious; even the teachers at school noticed it." (F22)

In the process of support and help, the children needed considerable encouragement from the students. The concept of the strength perspective helped them respond when recognising learned helplessness (Seligman, 1992) in some children, which is why it was so important for the students to give up not believing in them (Saleebey, 1997).

"I saw how important the strength perspective is when I taught $P_{3} \mathrm{D}_{2}$. Every time she started doing her homework, I encouraged her by saying 
that I knew she could do it, that she could take as much time as she needed, and that I believed she would complete the assignment." (PF3)

Parents and children also shared what they found most helpful in the co-creative working relationship. They liked the fact that the meetings were ongoing, that the student took time to talk to them, and that the work was carried out in the present, deriving from the needs the family members expressed "here and now".

"He also pointed out that he liked the way the project was aimed at working on the things one really needed and that the help was not predetermined." (PFE2.F11F.4)

They also liked the personal participation of the student.

"You knew how to listen; when something was wrong, you said it in a powerful but nice way. You managed to build a genuine relationship; you knew when to be strict and when to be friendly. You always said it in a nice way, not in a harsh way." (PFE2.F7M.9)

Family members highlighted common conversations; they felt safe and relaxed enough to express their suggestions and desires, and to be heard and appreciated.

"I would also assess it with 10 out of 10; I was heard and I really liked the way you appreciated me." (PFE1.F7D.6)

They emphasised the importance of reaching joint agreements.

"I think that the conversations and agreements were very useful. We agreed on our tasks together and divided them; it was not always the same person who had to do something." (PFE4.F7D.23)

They found it important that the students joined the family without imposing their opinions on them.

"And you never imposed anything, only suggested it." (FE5.F9D.24)

They highlighted the so-called principle of interposition (Lüssi, 1991).

"I do not know how you were able to approach us all in the same way" (PFE5.F7M.25)

They liked the fact that they could develop their new behaviour through the experience of how the student acted in a given situation. 
"Or, for example, I saw how you work with F9S1 and I tried it myself." (FE5.F9D.25)

\section{The Student as an Important Adult in the Family}

The student who joined the family as an appreciative and accountable ally represented an opportunity for new hope. Hope can be given to someone as a gift, when family members and so-called mentors help them recognise and encourage their internal capabilities to achieve their goals and to fulfil their greatest potential in life (Maholmes, 2014, p. 97). The families found the students' learning assistance very valuable, as they often felt helpless and could not or did not know how to help their children despite their desire and willingness, which made them even more burdened.

"She was worried because F9S1 got nothing but fail grades and she was afraid that he would have to repeat the third year. She said that she sometimes did not know how to help him and that they sometimes did homework for hours. However, she had enough strength to attend the parentteacher meetings and to ask how her daughter and son were doing in school. I offered to come once a week and help them do their homework and study. She immediately accepted my proposal and we agreed that I would come every week in the afternoon." (F9)

The parents want the children to perform well at school, and the children share this desire. This was highlighted by Maholmes (2014, p. 70), who claimed that parents who face serious adversities and severe life circumstances want their children to have opportunities that they might not have themselves. They have aspirations and dreams for their children, and take the necessary steps to achieve these dreams. In initial expectations, when defining the greatest goal they want to achieve for themselves and their family by participating in the IWPH, the parents emphasised the better school performance of their children.

"It would mean a lot to me if my children did well in school." (E2.F9M.5)

Parents consider a child's good school performance to be a significant protective factor for both the child and the family.

"At the first meeting, PF11F said that he was worried about his daughter's education, that PF11D would need help in learning maths, English and German." (PSF11)

With the help of the students, the parents gained a new insight into their 
children's learning difficulties.

"That I put their daughters' poor school performance into context; that they are not lazy and naughty, but affected by all the troubles the family has and confused because they speak two languages at home (the father does not speak Slovenian)." (F15)

They realised how important their support is in improving school performance.

"My work showed the family how important it is for all family members to participate in learning support for the child. It is particularly beneficial for children with poor school performance to feel the support of their parents, for their parents to encourage them continually. The children need compliments, they need to be noticed and praised regularly. During the IWPH process, the parents constantly motivated their children and became increasingly involved in the children's school life." (F21, 22)

The children found collaboration with the student significant and valuable. They began to trust themselves more, their self-confidence increased, they gained skills for independent learning, they overcame their fear of school and their attendance improved.

" $P F 7 D$ started to go to school every day, which will enable her to get the necessary and missing marks and to achieve her goal of finishing school." $(\mathrm{PF} 7)$

Support, leadership and encouragement are central components of the so-called mentoring relationship, as the relationship that developed between the children and the students during learning assistance could be called. As stressed by Maholmes (2014, p. 103), it is essential that the relationship is stable and long-term in order to co-create effective outcomes. Since the experience of poor school performance was often long-lasting, there was sometimes a need for time and a new positive experience to end the prevailing story of failure. In two cases, the child had to repeat a year or change schools despite the student's help; however, this does not imply that the collaboration was entirely unsuccessful, as the path the student and the child followed together included a new, positive experience.

\section{The Experience of Meaningfulness and Trust Opens New Family Working Topics}


During the collaboration with the families in the IWPH, learning assistance often proved to be an opportunity to open other working topics in order to support and help the family.

"We decided to schedule our conversation every Friday morning so that she could talk to someone and share her thoughts. As she herself said, she does not have any friends or other loved ones she could talk to. F9D sometimes joined our conversations; we discussed various topics, such as job search, paperwork for compulsory and supplementary health insurance, ways to calm F9S1 down, what works and what doesn't." (F9)

During the collaboration process, the family increasingly trusted the student, thus leading to important changes in the process of helping the family.

"The next shift in our relationship was that PF11D opened up to me. I believe this happened when she wanted to cancel the meeting, saying that she did not feel like studying. I nevertheless invited her for a coffee. We talked about other things - PF11D talked about her personal life, relating various anecdotes, and about her father, as well about her mother and her suicide. Although the meeting was like a conversation over coffee, I believe that it deepened our relationship immensely. It represented the moment of 'kairos'. We thus had two separate spaces: the space in her home, where the topic was school, and the space in the coffee shop, where the topic was her personal life." (PF11)

It provided an opportunity to consider a new working topic with the family and to help children in other areas of their lives.

"After learning assistance, the lady turned to me; she was in distress because she felt that she was sometimes unable to establish a good relationship with F22S and that she found it easier to yell at him than to maintain her self-control. We talked about motivating F22S, about different ways of encouraging children to study. The woman was grateful for the conversation and the help I offered $F_{22} S$, as it enabled her to develop a different way of thinking about her problem and the possible solutions." (F22)

The family's collaboration with the student substantially contributed to the functioning of the family as a working group; for instance, the family managed to agree on some family rules.

"With my help, the family started to negotiate when and who would do the chores. Order was restored and the rules on a cleaning, washing and vacuuming schedule were established." (PF7) 
Participation in the project sometimes led to changes in family communication and joint leisure activities.

"When the father comes home, they talk more. The father used to yell at them very often and now he does not do it anymore." (PF7)

Learning assistance also contributed to better family cohesion and improved relationships within the family. Support for multi-challenged families on the relational level is essential for the success of the help processes, as strong, stable relationships are a key protective factor against the psychological and behavioural consequences of living in poverty (Maholmes, 2014, p. 54).

"They were delighted because it developed into part of the game; it strengthened their relationship and gave them a tangible feeling that each and every one of them can help achieve the accessible goal." (F22)

During the initial expectations survey, some families mentioned other working topics that would improve their living situation (e.g., getting a job, solving the housing issue, regulating the rights from public funds). The aim of the families was to solve personal problems in order to improve the relationships within the family, both with the children and between partners.

"She said that she would like to change her life, since she cannot live like this anymore. According to her own words, she lies and sleeps all day; she does not go anywhere and is shut away within four walls. In addition, she is retired due to her disability status and her diagnosis of mental problems." (PE2.F7M.1)

\section{The Importance of Collaboration in the Family's Home}

The students recognised the advantages of working with the families within the project in the fact that the work was carried out in family's home, in the community.

"I also liked the fact that we carried out fieldwork in the user's home. I believe it is easier to work in the user's home environment, where they feel safer and are not under the pressure of an institution." (PF3)

The students considered working with the family in the community to be an important success factor in the process of collaborating with the family. Collaboration at home allowed them to learn about the complexity of everyday family life and facilitated an understanding of family stories. Madsen (2007, p. 26) says that we should join the family as an original culture and learn about this culture as 
much as possible in order to understand the complexity of individual families. The students believe that collaboration at home facilitated joining the family.

"I learned how important fieldwork in the user's home is for social workers; not only to evaluate and control on the basis of public powers, but also to give up the power social workers have as professionals in order to explore the resource and strength perspective sensitively. In the official social centre premises, families are focused on an attractive appearance, on putting on a nice front; when working together at home, however, we can more easily see the distress that needs to be restructured into joint work on changes and possible goals through the working relationship." (D21, 22)

\section{Connecting with Other Institutions}

When providing children with learning assistance, the students recognised the importance of collaboration with other institutions, especially with the school.

"Collaboration with the school proved to be effective, the school being an important partner in the project of providing help. During the process, I got to know how important it is to collaborate with other institutions to co-create help, particularly when the help and the solution depend on the institution." (PF11)

Collaboration with the school often involved support for the child in overcoming learning difficulties, thus contributing to the child's better school performance. When collaborating with the school and other institutions, the main question is how to ensure collaboration and what kind of collaboration to offer. In the IWPH (Čačinovič Vogrinčič, Kobal, Mešl, \& Možina, 2005), collaboration protects the space for co-creating agreements, whereby we hear and consider all of the voices, and for building the path to the desired changes, whereby all of the participants contribute to the solution and support each other in taking the agreed steps.

"Our collaboration allowed us to look at $P F 7 D$ from different perspectives and choose a way of working for her without any disagreement. We all tried to listen to PF7D's desires and expectations and to respond to her needs. The collaboration enabled the school to be more supportive of $P F 7 D$, paying her more attention and discussing oral and written exams with her more thoroughly." $\left(P F_{7}\right)$

The students often showed initiative in establishing contact with the school and assumed the role of the child's defender, protecting the space for the child's voice. 
"In the next step, we agreed on a multidisciplinary meeting with the school psychologist, special educators and the school counselling service, where I had the role of PFyD's defender. Although she was not present at the meeting, I made sure that her voice was heard, I made space for her and drew up a work plan for her based on her voice." (PF7)

The analysis results confirm Malhomes' findings (2014, p. 70) that programmes of help that form partnerships with schools and other organisations provide the family with important resources. At the same time, they strengthen parents' psychosocial resources, facilitating the identification of their roles in developing children's skills to fulfil their life potential. What is more, the children also strengthen their resources as interlocutors in the process of co-creating the desired outcomes.

\section{Conclusion}

The working relationship and the IWPH contribute to the co-creation of the desired outcomes and strengthen family resilience. The project aimed to go beyond the dominant discourse on multi-challenged families, i.e., social workers often believe that these families do not want to receive help (Bouwkamp \& Bouwkamp, 2014, p. 297). The problem with this discourse is that, in the process of help, issues of failure are often identified as being characteristic of families (ibid.). In a co-creative working relationship, all of the participants contribute to solutions, while the social worker is responsible for leading the process of help and creating a safe space for collaboration. Madsen (2007, p. 33) also believes that collaborating in partnership and adapting services to the family's needs are essential for the success of the processes of help.

The results of the plural case study confirm the importance of collaborating with multi-challenged families dealing with a child's poor school performance. It is important to accept the initial definition of the problem and the outcomes desired by the family members. At first, the latter may be focused on learning assistance to the child, but on gaining trust and experiencing the meaningfulness of collaboration we respond to new working topics raised by the family during joint conversations.

Life in poverty and related unfavourable circumstances should not define children's life stories. The experience of good school performance is an important protective factor in a child's life. Dryfoos (in Boyd-Franklin \& Hafer Bry, 200o, p. 121) even concludes that good school performance is the only larger predictor of a child's future. Knowing this, adults are obliged to enable 
good school performance for every child. Parents who face many stresses want to help their children and support them in improving school performance, but they often need assistance. The co-creative working relationship and the IWPH, co-created by all of the participants, support children and parents, enabling them to fulfil their desire for success. The project needs to connect resources in the community and to conceive a joint project. The child's role as an expert on experience whose voice is protected and appreciated is important for collaboration.

When the social worker joins the family with a positive attitude, this attitude is internalised by family members (Bouwkamp \& Bouwkamp, 2014, p. 298). As an appreciative and accountable ally (Madsen, 2007), the social worker brings new hope to the family, acting as a motivation to overcome distress (Maholmes, 2014). The presence of a social worker who persists in a joint project even in the case of failure represents an important new experience for the family. Only this can overcome the despair that is a common companion of people in difficult life situations, including multi-challenged families.

Even in families where it seems that risks predominate in relation to protective factors, collaboration with the family can always highlight many resources. Although families are resilient (Walsh, 2006; Maholmes, 2014), they sometimes need an interlocutor to help them recognise and strengthen that resilience. On the first level, family resilience is strengthened through the experience of collaborating in a co-creative working relationship when solving a complex psychosocial issue. It is also increased on the second level, when contributing to the increased visibility of family processes and exploring the desired changes in relationships (Mešl, 2013). The experience of good school performance, which we are obliged to ensure for children, strengthens the child's resilience and the resilience of the entire family.

The context of helping families in their homes is an opportunity to get to know family members on an everyday human level. Working at home helps discover family resources when searching for answers to the challenges of life circumstances. Social work with families at home is no longer an abstract idea, but is becoming an everyday practice. We believe that this is the answer to the question of how to develop social work in the future. As Madsen (2007, p. 36), who himself works with families in their homes, says, the conversations can take place over coffee, at the kitchen table or in the living room, where we are surrounded by family photos. We suddenly become guests and not professionals with solutions, which changes the way of collaborating with people. 


\section{References}

Boyd-Franklin, N., \& Hafer Bry, B. (200o). Reaching Out in Family Therapy: Home-based, school, and community interventions. New York: The Guilford Press.

Bouwkamp, R., \& Bouwkamp, S. (2014). Blizu doma. Priročnik za delo z družinami [Close to home. Manual for working with families]. Ljubljana: Znanstvena založba FF, Pedagoška fakulteta, Inštitut za družinsko terapijo.

Čačinovič Vogrinčič, G., Kobal, L., Mešl, N., \& Možina, M. (2005). Vzpostavljanje delovnega odnosa in osebnega stika [Establishment of Working Relationship and Personal Contact]. Ljubljana: Fakulteta za socialno delo.

Čačinovič Vogrinčič, G. (2008). Socialno delo z družino [Social Work with Families]. Ljubljana:

Fakulteta za socialno delo.

Čačinovič Vogrinčič, G. (2013). Spoštovanje otroštva [Respecting Childhood]. In T. Kodele, \& N. Mešl (Eds.), Otrokov glas v procesu učenja in pomoči. Priročnik za vrtce, šole in starše [Child's Voice in the Processes of Learning and Help. Manual for Kindergartens, Schools and Parents.] (pp. 11-40). Ljubljana: Zavod RS za šolstvo.

Hoffman, L. (1994). A Reflexive Stance for Family Therapy. In Sh. McNamee, \& G. J. Gergen (Eds.), Therapy as Social Construction (pp. 7-24). London: Sage.

Jong, de P., \& Kim Berg, I. (2002). Interviewing for Solutions (2nd ed.). Pacific Grove USA: Brooks/

Cole.

Lüssi, P. (1991). Systemische Sozialarbeit [Systematic Social Work]. Bern: Haupt.

Madsen, W. C. (2007). Collaborative Therapy with Multi-Stressed Families. New York: The Guilford Press.

Maholmes, V. (2014). Fostering Resilience and Well-Being in Children and Families in Poverty: Why Hope Still Matters. New York: Oxford University Press.

Mesec, B. (1998). Uvod v kvalitativno raziskovanje v socialnem delu [Introduction in Qualitative Research in Social Work]. Ljubljana: Visoka šola za socialno delo.

Mešl, N. (2013). Od razumevanja pojava naučene nemoči k razvijanju odpornosti v socialnem delu [From Understanding Learning Helplessness to Developing Resilience in Social Work] Socialno delo, $52(6), 351-360$.

Saleebey, D. (1997). The Strength Perspective in Social Work Practice. New York: Longman.

Seligman, M. (1992). Helplessness. New York: Freeman.

Walsh, F. (2006). Strengthening Family Resilience ( $2^{\text {nd }}$ ed.). New York: The Guilford Press. 


\section{Biographical note}

NinA MEŠL, PhD, is an Assistant Professor at the Faculty of Social Work, University of Ljubljana. Her areas of research and teaching are processes of support and help in social work, with special interest for social work with families.

TAdeja Kodele, Master of Science, with eduaction in social work. She is employed at Faculty of Social Work, University of Ljubljana, as assistant lecture and researcher. Her areas of research and teaching are social work with youth and social work with families. 